\title{
Isolation and selection of bacteria against shrimp pathogenic vibrio parahaemolyticus from shrimp pond water on Duyen Hai district, Tra Vinh province
}

\author{
Tran Vu Phuong ${ }^{*}$, Dang Thi Ngoc Thanh ${ }^{2}$, Cao Ngoc Diep ${ }^{1}$ \\ ${ }^{1}$ Biotechnology R\&D Institute, Can Tho Universty, Vietnam \\ ${ }^{2}$ Sai Gon University, Vietnam \\ *Corresponding author: tvuphuong@ctu.edu.vn
}

\begin{tabular}{|c|c|}
\hline ARTICLE INFO & ABSTRACT \\
\hline $\begin{array}{l}\text { DOI:10.46223/HCMCOUJS. } \\
\text { tech.en.10.1.359.2020 }\end{array}$ & $\begin{array}{l}\text { Antibiotic has frequently been used in the shrimp-farming } \\
\text { process in Vietnam. This leads to the status that antibiotic- } \\
\text { resistant bacteria and products do not receive in the market. } \\
\text { Bacteria had the resistant ability to pathogenic bacteria in water, } \\
\text { and they have an important role in sustainable aquaculture. This } \\
\text { study aimed to isolate and select good bacterial strains against }\end{array}$ \\
\hline $\begin{array}{l}\text { Received: October } 1^{\text {st }}, 2019 \\
\text { Revised: November } 13^{\text {th }}, 2019 \\
\text { Accepted: November } 21^{\text {st }}, 2019\end{array}$ & $\begin{array}{l}\text { Vibrio parahaemolyticus, pathogenic bacteria, on shrimp from } 8 \\
\text { samples of shrimp pond water at } 3 \text { villages Ngu Lac, Phuoc An } \\
\text { and Long Toan of Duyen Hai district, Tra Vinh province on NB } \\
\text { agar medium. As a result, fifty-nine bacterial isolates were } \\
\text { isolated and } 10 / 59 \text { isolates ( } 16.95 \% \text { ) were identified as resistant } \\
\text { to Vibrio parahaemolyticus by the good diffusion method. In } 10 \\
\text { isolates, there were } 7 \text { isolates that had good resistance to selection }\end{array}$ \\
\hline $\begin{array}{l}\text { Keywords: } \\
\text { antimicrobial, bacteria, } \\
\text { shrimp-pond water, Vibrio } \\
\text { parahaemolyticus }\end{array}$ & $\begin{array}{l}\text { for PCR technique and sequencing. The result indicated that these } \\
\text { seven strains, including DH1m, DH2f, DH4d, DH8i, DH8m, } \\
\text { DH8n, belonged to Bacilli and the DH1n strain belonged to } \\
\text { Streptomyces sp. }\end{array}$ \\
\hline
\end{tabular}

\section{Introduction}

Shrimp cultivation has been faced with pathogenic bacterial infections, such as luminous vibriosis and acute hepatopancreatic necrosis disease (AHPND) caused by Vibrio harveyi and Vibrio parahaemolyticus, respectively (Chumpol et al., 2019). Shrimp production in Southeast Asia steadily averaged 6.0\% annual growth from 2008 to 2011; however, the production declined from 3.45 million metric tons (MMT) to 3.25 MMT in 2012 (down 5.8\%) and 3.21 MMT in 2013 (down 1.1\%) due to the impact of early mortality syndrome (EMS) in China, Thailand, Vietnam, and Malaysia (Anderson, 2016). EMS is also called the acute hepatopancreatic necrosis disease (AHPND) and is infectious with the symptoms including sloughing of hepatopancreas (HP) cells, enlarged HP nuclei, and lack of B, F, R cells and E cell mitosis (Food and Agriculture Organization of the United Nations (FAO), 2013). The outbreak of AHPND/ EMS in Thailand was first reported in late 2012 in pacific white shrimp farming 
on the eastern coast, and then spreading to the west coast facing the Gulf of Thailand (Flegel, 2012; Joshi et al., 2014). It caused 100\% mortality early on in shrimp cultures, at around 20-30 days of cultivation; and V. parahaemolyticus is recognized as the bacterial strain that caused AHPND/EMS (Tran et al., 2013).

To solve these problems, shrimp farmers normally use antibiotics to eliminate pathogenic bacteria; however, antibiotics can be harmful to consumer health. Also, long term use of antibiotics leads to residual compounds in sediment and water, and the bacteria can adapt themselves by selecting for antibiotic-resistant genes (Zhang, Li, \& Sun, 2011). For sustainable shrimp cultivation, probiotics and/or their anti-vibrio compounds as biocontrol agents have been explored to control vibriosis in shrimp farming. Gram-negative and gram-positive bacteria have been identified as potential probiotics for aquaculture, with effects against various pathogens (Brunt, Newaj-Fyzyl, \& Austin, 2007). The aim of this work was to isolate, select, and identify bacterial isolates having good resistance to $\mathrm{V}$. parahaemolyticus in the water of shrimp pond on Duyen Hai district, Tra Vinh province, Vietnam to produce a probiotic for shrimp cultivation.

\section{Materials and methods}

\subsection{Materials}

Water samples were collected at the depth of $0.2 \mathrm{~m}$ and distance shore $4 \mathrm{~m}$, from 8 shrimp-ponds of 3 villages (Long Toan, Ngu Lac, Dinh An) (9 64'37' to 967'88' East and $106^{\circ} 45^{\prime} 29$ " to $106^{\circ} 51^{\prime} 73^{\prime \prime}$ North) of Duyen Hai district, Tra Vinh province, Vietnam, they stored in an icebox and transferred to Can Tho University laboratory, stored $-4^{\circ} \mathrm{C}$ in the refrigerator until analysis.

Vibrio parahaemolyticus provided by Dr. Đang Thi Hoang Oanh, Department of Aquaculture Pathology, College of Aquaculture, Can Tho University.

Nutrient Agar (Difco) medium supplemented with Aginalxic (10 $\mathrm{g} / \mathrm{l})$ and Nystatin $(25 \mu \mathrm{g} / \mathrm{l})$ into the medium after autoclaving; Luria Bertani medium (Sambrook, Fritsch, \& Manlatis, 1989).

\subsection{Methods}

\subsubsection{Isolation and culture}

Water samples were serially diluted with sterile saline water $(0.01 \%)$. A hundred microliters of the suspensions were spread onto the NB agar medium. All plates were inoculated at room temperature for $24 \mathrm{~h}$; the disjointed colonies were recorded and re-streaked to obtain a pure culture. The colonies bearing distinct morphological characteristics were picked up and transferred to freshly prepared media until pure cultures were obtained.

\subsubsection{Screening assays for antibacterial activity}

The liquid cultures were grown with shaking at 150rpm for 1 day depending on their growth rate at $30^{\circ} \mathrm{C}$. The broth was centrifuged in $50 \mathrm{~mL}$ falcon tubes $(5000 \mathrm{rpm}, 15 \mathrm{~min}$ at room temperature; Megafuge 1.0R, Heraeus) and the supernatant was stored at $4{ }^{\circ} \mathrm{C}$. The bacterial test organisms were plated in the LB medium. The antimicrobial extract was added to the wells; the 
plates were incubated at $4{ }^{\circ} \mathrm{C}$ for $2 \mathrm{~h}$ for the diffusion of antimicrobial extract and observed for the zones of inhibition at $28^{\circ} \mathrm{C}$ for $48 \mathrm{~h}$.

\subsubsection{The Agar well diffusion method}

The active isolates were cultured by the method given in the previous step. The supernatants were used for testing extracellular antimicrobial activity by agar well diffusion method. By using a sterile cork borer, wells were punctured in an appropriate agar medium previously seeded with one of the test organisms. One hundred microliters of the culture supernatants were added to each well. The plates were then incubated at $4^{\circ} \mathrm{C}$ for at least $2 \mathrm{~h}$ to allow the diffusion of crude extracts followed by incubation for $24 \mathrm{~h}$ at $37^{\circ} \mathrm{C}$ for bacteria and $48 \mathrm{~h}$ at $28^{\circ} \mathrm{C}$ for yeast. The diameters of inhibition zones were monitored and measured (Galindo, 2004) and positive control was penicillin.

\subsubsection{Genomic DNA extraction}

Bacterial cells from these cultures were collected by centrifugation and genomic DNA was extracted (Sambrook et al., 1989).

\subsubsection{PCR amplification and sequencing of $16 \mathrm{~S}$ rDNA}

PCR was used with primer 27F (5'-AGAGTTTGATCCTGGCTCAG-3') (Weisburg, Barns, Pelletier, \& Lane, 1991) and 1492R (5'-TACGGTTACCTTGTTACGACTT-3') (Reysenbach, Giver, Wickham, \& Pace, 1992) Cycling condition was as follows: initial denaturation at $95^{\circ} \mathrm{C}$ for $5 \mathrm{~min}, 30$ cycles of $95^{\circ} \mathrm{C}$ for $30 \mathrm{sec}, 55^{\circ} \mathrm{C}$ for $30 \mathrm{sec}$, and $72^{\circ} \mathrm{C}$ for 90 sec, and a final extension of $5 \mathrm{~min}$ for $72^{\circ} \mathrm{C}$.

\subsubsection{Sequence analysis}

The 16S rRNA gene sequences were compared with those from the type strains available in NCBI (http://www.ncbi.nlm.nih.gov/) using the Basic Local Alignment Search Tool (BLAST) (Altschul, Gish, Miller, Myers, \& Lipman, 1990).

For phylogenetic analysis, multiple sequence alignment was performed using CLUSTALX, version 1.81. The phylogenetic tree was constructed using Mega 7.0 (Kumar,

Stecher, Li, Knyaz, \& Tamura, 2018). The consistency of the trees was verified by bootstrapping (1000 replicates) for maximum likelihood.

\subsubsection{Data analyses}

The experimental results were analyzed as a two-way ANOVA with the isolates and with levels of diameters of inhibition zones. All analyses were conducted using the program MSTATC, Minitab 16. The data were considered significantly different at $\mathrm{P}<0.01$. Duncan test at $\mathrm{P}=0.01$ was used to differentiate between statistically.

\section{Results and discussions}

\subsection{Isolation of bacteria}

A total of 59 isolates of bacteria was purified from 8 water samples collected at 3 sites (Long Toan, Phuoc An and, Ngu Lac). 


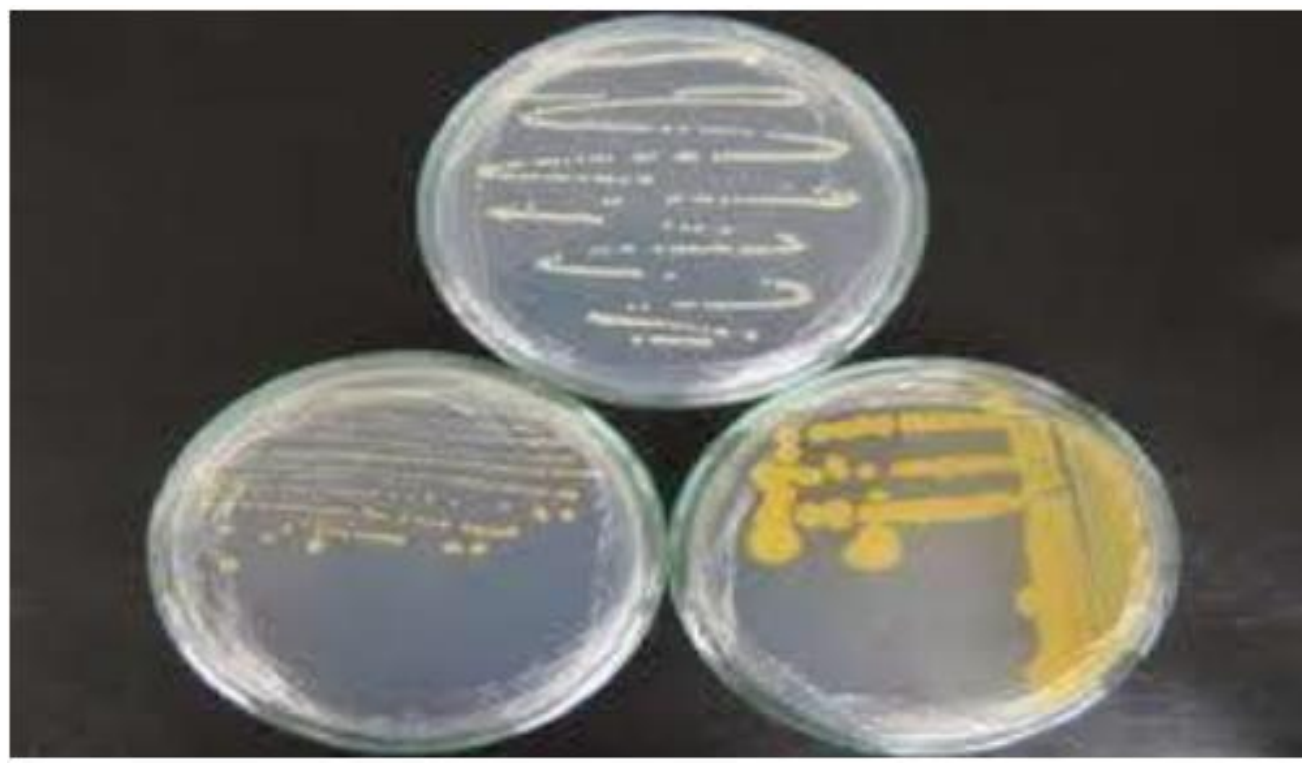

Figure 1. Shape and size of several colonies

Almost their colonies have round-shaped; milky or less yellow, diameter size of colony $>2 \mathrm{~mm}$, and yellow, entire or lobate margin, pulvinate elevation; diameter size of these colonies varied from 0.2 to $3.0 \mathrm{~mm}$ (Figure 1) and all of them have Gram-positive. Seven of 59 tested isolates could produce antimicrobial active metabolites inhibiting V. parahaemolyticus (Table 1).

\section{Table 1}

Antimicrobial activity of 10 bacterial isolates to Vibrio parahaemolyticus

\begin{tabular}{|c|c|c|c|c|c|}
\hline No & $\begin{array}{c}\text { Bacterial } \\
\text { isolates }\end{array}$ & $\begin{array}{c}\text { Inhibition zone } \\
\text { diameter } \\
[\mathbf{D}=\mathbf{d} \text { - } \mathbf{d} \text { 2 }] \mathbf{( m m})\end{array}$ & No & $\begin{array}{c}\text { Bacterial } \\
\text { isolates }\end{array}$ & $\begin{array}{c}\text { Inhibition zone } \\
\text { diameter } \\
{[\mathbf{D}=\mathbf{d} \text { - } \mathbf{d} \text { 2 }] \text { (mm) }}\end{array}$ \\
\hline 1 & DH 1m & $20.33 \mathrm{a}$ & 5 & DH $8 \mathrm{i}$ & $13.67 \mathrm{ef}$ \\
\hline 2 & DH 1n & $21.33 \mathrm{a}$ & 6 & DH 8m & $14.33 \mathrm{de}$ \\
\hline 3 & DH 2f & $17.33 \mathrm{bc}$ & 7 & DH 8n & $16.33 \mathrm{de}$ \\
\hline 4 & DH 4d & $19.33 \mathrm{ab}$ & 8 & $\begin{array}{c}\text { Positive control } \\
\text { (penicillin) }\end{array}$ & $11.67 \mathrm{~g}$ \\
\hline
\end{tabular}

Source: The researcher's data analysis

Means within a column followed by the same letter/s are not significantly different at $\mathrm{p}<0.05$.

Antimicrobial activity of two bacterial isolates showed through the sterile halo (Figure 2). 

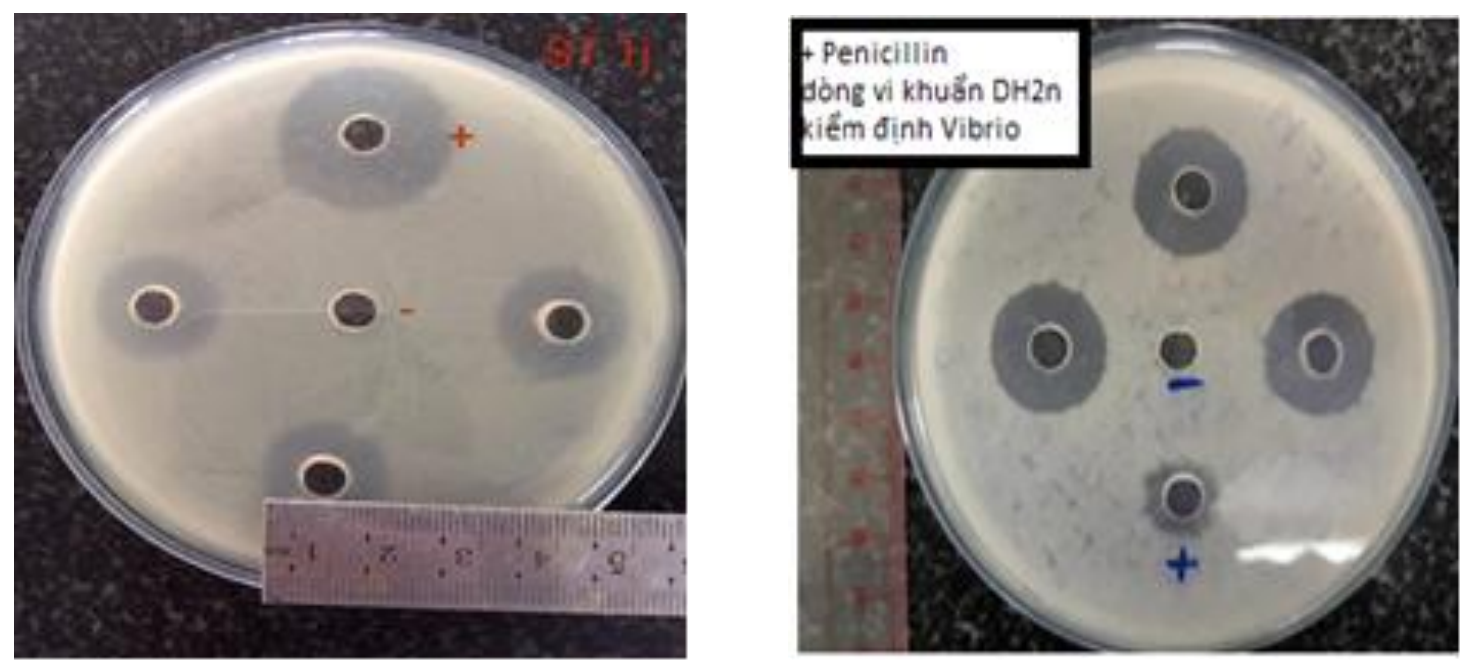

Figure 2. Antimicrobial activity of two bacterial isolates (DH8n and DH1n) against V. parahaemolyticus

\subsection{The identification of bacterial isolates}

Seven good bacterial isolates as follows: DH1m, DH1n, DH2f, DH4d, DH8i, DH8m, and DH8n were selected for PCR and sequencing. The result was presented in Table 3.

\section{Table 3}

Phylogenetic affiliation of isolates based on 16S rRNA gene sequences by using BLAST program in the GenBank database based on sequences similarity

\section{Taxonomic group and} strain
Similarity (\%)

\section{Bacilli}

DH1m

MK834692 Bacillus subtilis strain TBMAX53

98.90

KX668274 Bacillus tequilensis strain MS01

98.90

DH2f

MF077125 Bacillus tequilensis strain 52-LR1-2

99.36

GU980947 Bacillus subtilis strain CICC 10023

99.26

DH4d

EU153188 Bacillus subtilis strain JPC-2

99.84

MK014304 Bacillus sp. strain DM2

99.76

DH8i

MK719884 Bacillus siamensis strain Q13

99.60

KY652945 Bacillus amyloliquefaciens strain

99.60

DH8m isolate G12

99.84

KF922381 Bacillus sp. B1(2014b)

99.84

DH8n

99.11 


\begin{tabular}{ccc}
$\begin{array}{c}\text { Taxonomic group and } \\
\text { strain }\end{array}$ & \multicolumn{1}{c}{ Closest species relative } & $\begin{array}{c}\text { Similarity } \\
(\boldsymbol{\%})\end{array}$ \\
\hline & $\begin{array}{l}\text { KJ496372 Bacillus flexus strain MS14-1 } \\
\text { KR999908 Geobacillus stearothermophilus } \\
\text { strain NB3-8 }\end{array}$ & 99.11 \\
Proteobacteria & \multicolumn{1}{c}{99.77} \\
DH1n & JF751041 Streptomyces sp. 2011 \\
\hline
\end{tabular}

Source: The researcher's data analysis

A sequence of DN1n isolate searched on NCBI data bank, its similarity with Pseudomonas... with $99.77 \%$, in this table, however, there is only a strain Streptomyces sp. (a positive-gram bacteria) which has also the similarity with DN1n isolate with $99.77 \%$ we can select this strain to replace Pseudomonas sp. in the phylogenetic tree. Furthermore, the result of gram strain showed that all of the isolated bacteria were gram-positive therefore DH1n isolate was selected as gram-positive instead of gram-negative.

A UPGMA phylogenetic tree (Figure 3) in these strains showing the two clusters: cluster A with 6 strains including two smaller clusters as cluster A1 with 4 strains (Bacillus subtilis DH1m, Bacillus velezensis DH8m, Bacillus amyloliquefasciens DH8i, B. tequilensis GH2f) while cluster A2 with 2 strains were Streptomyces sp. DH1n and Bacillus subtilis DH4d. Cluster B only had one strain Bacillus flexus DH8n. Even though 7 strains originated from 3 sites far from many kilometers, but they had their genetics closely.

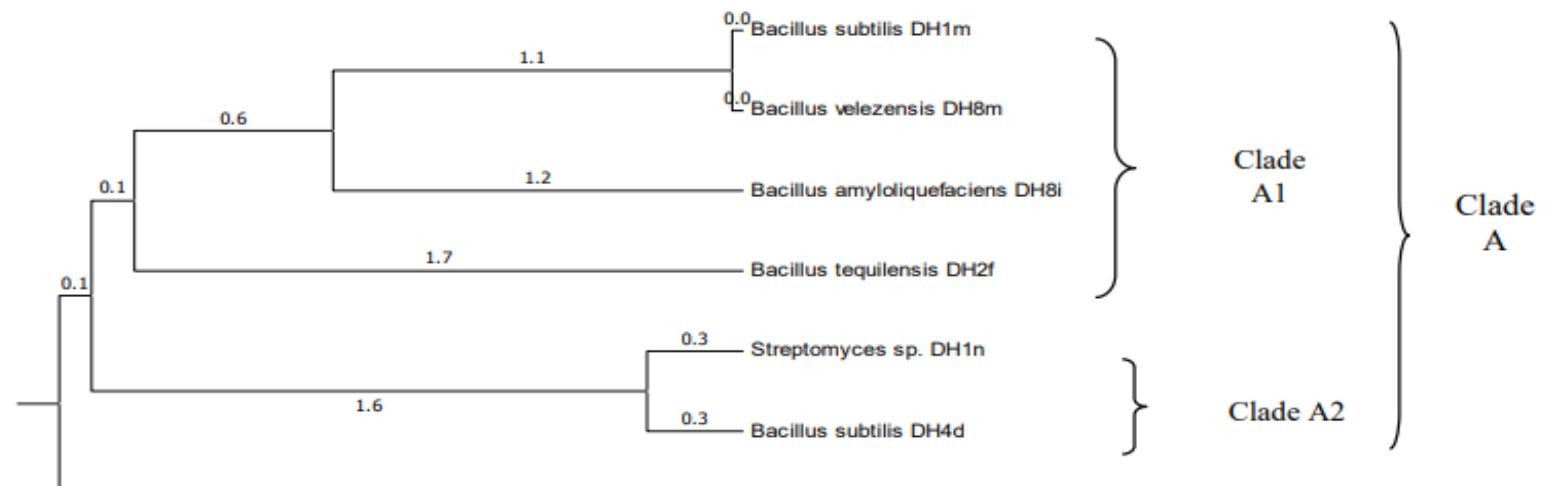

Clade B

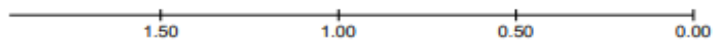

Figure 3. UPGMA phylogenetic tree of partial 16S rRNA gene sequences from the bacterial isolates from water pond-shrimp and closely related type strains. Numbers are the percentage bootstrap values that were calculated for 1000 replicates. Bar, 0.02 was per nucleotide position 
Vibrio species are among the most important bacterial pathogens of cultured shrimp. They are responsible for several diseases and mortalities of up to $100 \%$ due to vibriosis have been reported (Karunasagar, Pai, Malathi, \& Karunasagar, 1994). In the search for more effective and environmentally friendly treatments, probiotics have emerged as a viable alternative (Balca'zar et al., 2006; Verschuere, Rombaut, Sorgeloos, \& Verstraete, 2000). Probiotics are defined as live microorganisms that confer a health benefit on the host when consumed in adequate amounts (Reid et al., 2003). The genus Bacillus has been isolated from crustacean intestine (Rengpipat, Rukpratanporn, Piyatiratitivorakul, \& Menasaveta, 2000), bivalves (Sugita, Tanaami, Kobashi, \& Deguchi, 1981), and marine fish (Sugita, Hirose, Matsuo, \& Deguchi, 1998). Some species of this genus have shown inhibitory activity against various pathogens (Rengpipat, Phianphak, Piyatiratitivorakul, \& Menasaveta, 1998; Sugita et al., 1998).

In addition, several studies have reported that Bacillus produces polypeptide antibiotics, such as bacitracin, gramicidin S, polymyxin, and tyrotricidin, which are active against a wide range of Gram-positive and Gram-negative bacteria (Drablos, Nicholson, \& Ronning, 1999; Morikawa, Ito, \& Imanaka, 1992; Perez, Suarez, \& Castro, 1993).

Balca'zar and Rojas-Luna (2007) discovered the bacterial strain Bacillus subtilis UTM 126 produced antimicrobial activity against pathogenic Vibrio species, including V. alginolyticus, V. parahaemolyticus, and V. harveyi. The treatment with B. subtilis UTM 126 decreased final mortality to $18.25 \%$, compared with $51.75 \%$ in the control group. Bacillus subtilis UTM 126 has potential applications for controlling pathogenic V. harveyi in shrimp aquaculture.

Recently, Vidal, Pessoa, Dos Santos, Mendes, and Mendes (2018) recognized that B. cereus isolate from the intestine of shrimps Litopenaeus vannamei can colonize the intestine of post-larvae shrimps of the same species and promote a significant reduction of pathogens, with great effectiveness in reducing the pathogenic bacteria V. parahaemolyticus and V. alginolyticus in shrimps grown in the laboratory. Chumpol et al. (2019) also found the probiotic purple non-sulfur bacteria (PNSB) are safe for use in producing antivibration compounds against shrimp pathogenic vibrios. The probiotic PNSB, Rhodobacter sphaeroides (SS15, TKW17) and Afifella marina STW181, released antivibration compounds inhibiting various shrimp pathogenic Vibrio spp.

\section{Conclusion}

Fifty-nine bacterial isolates were isolated from 8 water samples of pond-shrimp at 3 villages of Duyen Hai district, Tra Vinh province, Vietnam. Seven/59 isolates that had good resistance to Vibrio parahaemolyticus were selected to identify. The result showed that 6 strains belonged to Bacilli and one was Pseudomonas sp.

Two strains Streptomyces sp. DH1n and Bacillus subtilis DH1m had the highest antibacterial activity against Vibrio parahaemolyticus, they have a great potential to local probiotic production in shrimp farming. 


\section{References}

Altschul, S. F., Gish, W., Miller, W., Myers, E. W., \& Lipman, D. J. (1990). Basic local alignment search tool. Journal of Molecular Biology, 215(3), 403-410.

Anderson, J. M. (2016). Global shrimp survey: Goal 2016. Retrieved July 1, 2019, from Global Aquaculture Alliance website: http://advocate.gaalliance.org/global-shrimp-survey-goal2016/\#sthash. viqjDMFO.dpuf

Balca'zar, J. L., \& Rojas-Luna, T. (2007). Inhibitory activity of probiotic bacillus subtilis utm 126 against vibrio species confers protection against vibriosis in juvenile shrimp (litopenaeus vannamei). Current Microbiology, 55(5), 409-412.

Balca’zar, J. L., de Blas, I., Ruiz-Zarzuela, I., Cunningham, D., Vendrell, D., \& Mu'zquiz, J. L. (2006). The role of probiotics in aquaculture. Veterinary Microbiology, 114(3/4), 173186.

Brunt, J., Newaj-Fyzyl, A., \& Austin, B. (2007). The development of probiotics for the control of multiple bacterial diseases of rainbow trout, Oncorhynchus mykiss (Walbaum). Journal Fish Diseases, 30(10), 573-579. doi:10.1111/j.1365-2761.2007.00836.x

Chumpol, S., Kantachotea, D., Rattanachuayb, P., Torpeea, S., Nitodac, T., \& Kanzaki, H. (2019). Optimization of culture conditions for production of antivibrio compounds from probiotic purple nonsulfur bacteria against acute hepatopancreatic necrosis diseasecausing Vibrio parahaemolyticus and Vibrio spp. Aquaculture, 505, 72-83. doi:10.1016/j.aquaculture.2019.02.040

Drablos, F., Nicholson, D., \& Ronning, M. (1999). EXAFS study of zinc coordination in Bacitracin A. Biochimica et Biophysica Acta, 1431(2), 433-442. doi:10.1016/s0167 4838(99)00064-3

Flegel, T. W. (2012). Historic emergence, impact and current status of shrimp pathogens in Asia. Journal of Invertebrate Pathology, 110(2), 166-173.

Food and Agriculture Organization of the United Nations (FAO). (2013). Report of the FAO/MARD technical workshop on Early Mortality Syndrome (EMS) or Acute Hepatopancreatic Necrosis Syndrome (AHPNS) of cultured shrimp (Under TCP/VIE/3304). Hanoi, Vietnam: FAO Fisheries and Aquaculture.

Galindo, A. B. (2004). Lactobacillus plantarum 44A as a live feed supplement for freshwater fish. Retrieved July 4, 2019, from https://library.wur.nl/WebQuery/wurpubs/337034

Joshi, J., Srisala, J., Truong, V. H., Chen, I. -T., Nuangsaeng, B., Suthienkul, O., ... Thitamadee, S. (2014). Variation in Vibrio parahaemolyticus isolates from a single Thai shrimp farm experiencing an outbreak of acute hepatopancreatic necrosis disease (AHPND). Aquaculture, 428-429, 297-302. doi:10.1016/j.aquaculture.2014.03.030

Karunasagar, I., Pai, R., Malathi, G. R., \& Karunasagar, I. (1994). Mass mortality of Penaeus monodon larvae due to antibiotic-resistant Vibrio harveyi infection. Aquaculture, 128(3/4), 203-209. doi:10.1016/0044-8486(94)90309-3 
Kumar, S., Stecher, G., Li, M., Knyaz, C., \& Tamura, K. (2018). MEGA X: Molecular evolutionary genetics analysis across computing platforms. Molecular Biology and Evolution, 35(6), 1547-1549. doi:10.1093/molbev/msy096

Morikawa, M., Ito, M., \& Imanaka, T. (1992). Isolation of a new surfactin producer Bacillus pumilus A-1, and cloning and nucleotide sequence of the regulator gene, psf-1. Journal of Fermentation and Bioengineering, 74(5), 255-261.

Perez, C., Suarez, C., \& Castro, G. R. (1993). Antimicrobial activity determined in strains of Bacillus circulans cluster. Folia Microbiologica, 38(1), 25-28.

Reid, G., Sanders, M. E., Gaskins, H. R., Gibson, G. R., Mercenier, A., Rastall, R. A., ... Klaenhammer, T. R. (2003). New scientific paradigms for probiotics and prebiotics. Journal of Clinical Gastroenterology, 37(2), 105-118.

Rengpipat, S., Phianphak, W., Piyatiratitivorakul, S., \& Menasaveta, P. (1998). Effects of a probiotic bacterium in black tiger shrimp Penaeus monodon survival and growth. Aquaculture, 167(3/4), 301-313.

Rengpipat, S., Rukpratanporn, S., Piyatiratitivorakul, S., \& Menasaveta, P. (2000). Immunity enhancement in black tiger shrimp (Penaeus monodon) by a probiont bacterium (Bacillus S11). Aquaculture, 191(4), 271-288.

Reysenbach, A. L., Giver, L. J., Wickham, G. S., \& Pace, N. R. (1992). Differential amplification of rRNA genes by polymerase chain reaction. Applied and Environmental Microbiology, 58(10), 3417-3418.

Sambrook, J., Fritsch, E. P., \& Manlatis, T. (1989). In vitro amplification of DNA by the polymerase chain reaction. In J. Sambrook, E. P. Fritsch \& T. Manlatis (Eds.), Molecular cloning: A laboratory manual (2nd ed.) (pp. 2-35). Cold Spring Harbor, NY: Cold Spring Harbor Laboratory Press.

Sugita, H., Hirose, Y., Matsuo, N., \& Deguchi, Y. (1998). Production of the antibacterial substance by Bacillus sp. strain NM12, an intestinal bacterium of Japanese coastal fish. Aquaculture, 165(3/4), 269-280.

Sugita, H., Tanaami, H., Kobashi, T., \& Deguchi, Y. (1981). Bacterial flora of coastal bivalves. Bulletin of the Japanese Society for the Science of Fish, 47(5), 655-661.

Tran, L., Nunan, L., Redman, R. M., Mohney, L. L., Pantoja, C. R., Fitzsimmons, K., \& Lightner, D. V. (2013). Determination of the infectious nature of the agent of acute hepatopancreatic necrosis syndrome affecting penaeid shrimp. Diseases of Aquatic Organisms, 105(1), 45-55.

Verschuere, L., Rombaut, G., Sorgeloos, P., \& Verstraete, W. (2000). Probiotic bacteria as biological control agents in aquaculture. Microbiology and Molecular Biology Reviews, 64(4), 655-671.

Vidal, J. M. A., Pessoa, M. N. C., Dos Santos, F. L., Mendes, P. D. P., \& Mendes, E. S. (2018). Probiotic potential of Bacillus cereus against Vibrio spp. in post-larvae shrimp. 
Universidade Federal Rural do Semi-Árido Pró-Reitoria de Pesquisa e Pós-Graduação, 31(2), 495-503.

Weisburg, W. G., Barns, S. M., Pelletier, D. A., \& Lane, D. J. (1991). 16S ribosomal DNA amplification for phylogenetic study. Journal of Bacteriology, 173(2), 697-703.

Zhang, Y. B., Li, Y., \& Sun, X. L. (2011). Antibiotic resistance of bacteria isolated from shrimp hatcheries and cultural ponds on Donghai Island, China. Marine Pollution Bulletin, 62(11), 2299-2307. 